\title{
The pinewood nematode, Bursaphelenchus xylophilus, in Madeira Island
}

\author{
L. FONSECA ${ }^{1}$, J. M. S.CARDOSO ${ }^{1}$, A. LOPES ${ }^{1}$, M. PESTANA ${ }^{2}$, F. ABREU ${ }^{3}$, N. NUNES ${ }^{3}$, M. MOTA $^{4}$, \\ I. ABRANTES ${ }^{1}$
}

\author{
${ }^{1}$ IMAR-CMA, Department of Life Sciences, University of Coimbra, 3004-517 Coimbra, Portugal, \\ E-mail: luisbidarra@gmail.com; ${ }^{2}$ Laboratório de Qualidade Agrícola, RAM, 9135-372, Santa Cruz, Portugal; \\ ${ }^{3}$ Direcção Regional de Florestas, 9020-149 Funchal, Portugal; ${ }^{4}$ NemaLab-ICAAM, University of Évora, \\ 7002-554 Évora, Portugal
}

\begin{abstract}
Summary
The environmental conditions in Madeira Island are favorable for the presence and dissemination of the pinewood nematode (PWN), Bursaphelenchus xylophilus. Five hundred Pinus pinaster wood samples were collected in several forest areas and PWN was detected in $22.8 \%$ of the samples. Bursaphelenchus xylophilus isolates from Madeira Island displayed the species-specific diagnostic characters. A morphological variation in the female tail terminus was detected. In most females, the tail presented a broadly rounded terminus and, occasionally, a digitate terminus with a terminal nipple-like extension resembling a mucro. PCR ITS-RFLP analysis revealed that Madeira Island isolates exhibited patterns specific to the species B. xylophilus and similar to virulent isolates. Amplified ITS regions were further sequenced and no genetic diversity was found for this genomic region among 17 Portuguese isolates (Madeira Island and Continental Portugal). Phylogenetic analysis revealed that Portuguese isolates grouped with isolates from China, Korea and one isolate from Japan.
\end{abstract}

Keywords: Bursaphelenchus xylophilus; Madeira Island; morphology; pinewood nematode; ITS-RFLP; phylogeny

\section{Introduction}

The pinewood nematode (PWN), Bursaphelenchus xylophilus (Steiner \& Buhrer) Nickle, is the causal agent of pine wilt disease (PWD). Trees of the genus Pinus are the main hosts for the PWN, and transmission of the nematode from one tree to another is carried out by insects (Coleoptera-Cerambycidae), mainly belonging to the genus Monochamus (EPPO, 2009). Bursaphelenchus xylophilus is native from North America and it has been transported to Japan in the early XXth century and then spread into China, Korea and Taiwan. In 1999, PWN was reported for the first time in Europe, in Continental Portugal, associated with maritime pine, $P$. pinaster Ait. (Mota et al., 1999), and in 2008 it was detected in Spain (EPPO, 2009; Abelleira et al., 2011; Robertson et al., 2011). In 2009, PWN was also detected on $P$. pinaster, in Madeira Island, near Funchal, by Direcção Regional de Agricultura e Desenvolvimento Rural (Laboratório de Qualidade Agrícola) and Direcção Regional de Florestas, under an annual survey (Portaria n. ${ }^{\circ} 8 / 2010$ ).

In Madeira Island, the conditions are favorable for the spread of B. xylophilus: presence of the insect vector, $M$. galloprovincialis (Olivier) (Erber \& Aguiar, 1996); a large area of $P$. pinaster forest ( $70 \%$ of total planted area) and favorable climatic conditions (average annual temperature above $20^{\circ} \mathrm{C}$ ). Information concerning the distribution of $B$. xylophilus in Madeira Island is very important to assess its potential damage for forests and is fundamental to define strategies of control and management, to improve quarantine regulations and to prevent further spread of the disease.

The main objectives of this study were to investigate the distribution of B. xylophilus in pine forests of Madeira Island, to characterise morphologically and molecularly PWN isolates from Madeira Island by PCR ITS-RFLP analysis and to evaluate the genetic diversity by ITS rDNA sequencing.

\section{Materials and methods}

Following the detection of PWN in Madeira Island, a survey was conducted in $P$. pinaster trees, in different areas of Madeira and Porto Santo Islands, during January, February and March 2010, by the regional forestry services according to the official legislation (Portaria n. ${ }^{\circ} 8 / 2010$ ).

Five hundred pine wood samples were collected in Calheta (17 samples), Câmara de Lobos (1), Funchal (133), Machico (28), Porta do Sol (2), Porto Moniz (3), Ribeira Brava (10), Santa Cruz (188), Santana (56), São Vicente (59), and Porto Santo (3), at $1.5 \mathrm{~m}$ from the base of the trunk and at the crown, using a low-speed drill and stored 
inside plastic bags. Nematodes were extracted from each wood sample, using the Baermann funnel method (Hooper, 1986) or the tray method (Whitehead \& Hemming 1965), and observed using an inverted stereomicroscope. The identification of $B$. xylophilus was based on diagnostic morphological characters (Fonseca et al., 2008a; EPPO, 2009). Eight isolates (Table 1) were established and maintained in cultures of Botrytis cinerea Pars. grown on malt extract agar medium, and incubated at $25^{\circ} \mathrm{C}$ (Fonseca et al., 2008a) for further studies.

Morpho-biometrical characterisation of Bursaphelenchus xylophilus isolates from Madeira Island

Males and females of three isolates of B. xylophilus (BxMad16S, BxMad18SC and BxMAd22C), extracted from pine wood samples, were killed by heat in a drop of water on a cavity glass slide, mounted in water, viewed, photographed and measured immediately. Photographs were taken with a Nikon Eclipse E400 bright field light microscope using a Nikon ACT-2U digital camera. Measu- rements were performed on a Leitz Dialux 20 bright field light microscope with the help of a drawing tube.

Molecular characterisation of Bursaphelenchus xylophilus isolates from Madeira Island

ITS rDNA amplification and RFLP analysis

Hundreds of nematodes (without separation according to sex or developmental stage) from the eight B. xylophilus isolates from Madeira Island and from a Japanese PWN virulent isolate (BxJS10) were collected, washed several times in distilled water and concentrated by centrifugation. The resulting supernatant was removed leaving the pellet containing the nematodes and used for DNA extraction. Nematode DNA was extracted according to (Braasch et al., 2004). Pellets containing nematodes were homogenised using a plastic homogeniser (Biomedix) with $60 \mu \mathrm{l}$ of extraction buffer $(0.2 \mathrm{M}$ saccharose, $0.1 \mathrm{M}$ Tris- $\mathrm{HCl} \mathrm{pH}$ 9.2, $0.1 \mathrm{M} \mathrm{NaCl}, 50 \mathrm{mM}$ EDTA, $0.5 \%$ sodium dodecylsulfate) and incubated for $15 \mathrm{~min}$ at $70^{\circ} \mathrm{C}$. After incubation, $12 \mu \mathrm{l}$ of $8 \mathrm{M}$ potassium acetate was added, incubated

Table 1. Bursaphelenchus isolates sequenced in this study (origin, codes and accession numbers)

\begin{tabular}{|c|c|c|c|c|}
\hline Species & Origin & & Code & $\begin{array}{l}\text { ITS sequence } \\
\text { Acession Number }\end{array}$ \\
\hline \multirow[t]{19}{*}{ B. xylophilus } & $\begin{array}{l}\text { Portugal } \\
\text { (Madeira Island) }\end{array}$ & Funchal & BxMad1F & JF826218 \\
\hline & & Funchal & BxMad3F & JF826219 \\
\hline & & São Vicente & BxMad9SV & JF826220 \\
\hline & & São Vicente & BxMad4SV & JF826221 \\
\hline & & Machico & BxMad2M & JF826222 \\
\hline & & Santana & BxMad16S & JF826223 \\
\hline & & Santa Cruz & BxMad18SC & JF826224 \\
\hline & & Calheta & BxMad22C & JF826225 \\
\hline & $\begin{array}{l}\text { Portugal } \\
\text { (Continental) }\end{array}$ & Álcácer do Sal & BxPt11AS & JF826226 \\
\hline & & Grândola & BxPt12G & JF826227 \\
\hline & & Santiago do Cacém & BxPt15SC & JF826228 \\
\hline & & Alcácer do Sal & BxPt17AS & JF826229 \\
\hline & & Santa Comba Dão & BxPt19SCD & JF826230 \\
\hline & & Tábua & $\mathrm{BxPt} 21 \mathrm{~T}$ & JF826231 \\
\hline & & Mealhada & BxPt56M & JF826232 \\
\hline & & Oliveira do Hospital & BxPt60OH & JF826233 \\
\hline & & Góis & BxPt65GO & JF826234 \\
\hline & South Korea & & BxKAS & JF826235 \\
\hline & & & $\mathrm{BxKBG}$ & JF826236 \\
\hline \multirow[t]{2}{*}{ B. mucronatus } & $\begin{array}{l}\text { Portugal } \\
\text { (Continental) }\end{array}$ & & BmPt1 & JF826237 \\
\hline & & & BmPt2 & JF826238 \\
\hline
\end{tabular}


on ice for $15 \mathrm{~min}$ and centrifuged at $20000 \mathrm{~g}$ for $30 \mathrm{~min}$ at $4^{\circ} \mathrm{C}$. The supernatants were transferred to new tubes, $72 \mu \mathrm{l}$ of ice-cold 2-isopropanol was added and the mixtures were centrifuged at $20000 \mathrm{~g}$ for $30 \mathrm{~min}$ at $4^{\circ} \mathrm{C}$. The precipitates were washed with $500 \mu \mathrm{l}$ of ice-cold $70 \%$ ethanol, centrifuged for $20 \mathrm{~min}$ at $20000 \mathrm{~g}$ at $4^{\circ} \mathrm{C}$ and dried at room temperature. The DNA was resuspended in $25 \mu \mathrm{l}$ of sterilised distilled water.

A segment of rDNA containing the 5.8S gene, the ITS1 and ITS2 regions, and partial regions of $18 \mathrm{~S}$ and $28 \mathrm{~S}$ gene was amplified by PCR using forward primer 5'-CGTAACAAGGTAGCTGTAG-3' (Ferris et al., 1993) and reverse primer 5'-TTTCACTCGCCGTTACTAAGG3' (Vrain, 1993). PCR was carried out in $50 \mu \mathrm{l}$ reaction mixture containing $2 \mu \mathrm{l}$ of nematode DNA, $5 \mu \mathrm{l} \mathrm{Taq}$ buffer (50 mM KCl, $10 \mathrm{mM}$ Tris $\mathrm{pH} 9.0,1.5 \mathrm{mM} \mathrm{MgCl}_{2}, 1 \%$ TritonX100, $0.2 \mathrm{mg} / \mathrm{ml}$ BSA) (Q-Biogene,), $2 \mu \mathrm{l}$ of dNTPs $(2.5 \mathrm{mM}), 6 \mu \mathrm{l}$ of each primer $(5 \mu \mathrm{M}), 0.4 \mu \mathrm{l}$ of Taq DNA polymerase $(5 \mathrm{U} / \mu \mathrm{l})(\mathrm{Q}-\mathrm{Biogene})$, and $28.6 \mu \mathrm{l}$ of sterilised distilled water. The solution was firstly heated to $94^{\circ} \mathrm{C}$ for $2.5 \mathrm{~min}$ and then submitted to 40 cycles: $94^{\circ} \mathrm{C}$ for $1 \mathrm{~min}$, $55^{\circ} \mathrm{C}$ for $1 \mathrm{~min}$, and $72^{\circ} \mathrm{C}$ for $2 \mathrm{~min}$, and a final extension step at $72^{\circ} \mathrm{C}$ for $5 \mathrm{~min}$. The PCR product from each isolate was digested with $3 \mathrm{U}$ of restriction endonucleases $A l u \mathrm{I}$, HaeIII, Hinfl, MspI and RsaI according to the instructions provided by the manufacturer (Amersham Biosciences). Virulent/avirulent ITS restriction patterns were also analysed using the restriction endonuclease HhaI (Iwahori et al., 1998; Aikawa et al., 2003; Aikawa \& Kikuchi, 2007). PCR and restriction products were separated by electrophoresis on $1.5 \%$ and $2.5 \%$ agarose gel, respectively. Fragment sizes were estimated on the basis of molecular size using the Vilber Lormat Photo Documentation DP-001-SD Software.

\section{ITS rDNA sequencing and phylogenetic analysis}

The amplified ITS rDNA product, obtained as described above, from 17 Portuguese B. xylophilus isolates (8 from Madeira Island and 9 from Continental Portugal), two Korean B. xylophilus isolates and two Portuguese B. mucronatus isolates (Table 1) was purified using the Qiaquick PCR Purification Kit (Qiagen) and complete sequenced in both strands in an automatic sequencer Applied BioSystems 3130xl Genetic Analyzer under BigDye ${ }^{\circledR}$ Terminator v3.1 Cycle Sequencing Kit (Applied Biosystems) conditions, using the same primers used in PCR and IKF1 and IKF2 primers (Iwahori et al., 1998). Sequence analysis was carried out using BioEdit (Hall, 1999) and homologous sequences in the databases were searched using BLAST (Altschul et al., 1997). Phylogenetic tree was constructed by the neighbour-joining method (Saitou \& Nei, 1987) with 1000 replications of bootstrap in MEGA 4 (Tamura et $a l ., 2007)$ using the ITS sequences alignment of $B$. $x y$ lophilus and B. mucronatus isolates mentioned above and of other isolates present in GenBank database: BxPtPOT (Acession number EF446949), BxPt1w (AM157747), BxPtHF (AB277204), BxPtT (AB277208), BxSpEFA1 (HQ646254), BxCAJ (EF446945), BxCNJ3 (EF446944),
BxCSC (EF446947), BxCZZ (EF446952), BxJT4 (AB277207), BxJ1 (EF446943), BxJ18 (AB294736), BxJS10 (AB277206), BxJOKD1 (AB277205), BxJC14-5 (AB277203), BxUSA2 (EEF446951), BxCanada (EF446946), BmDE4w (AM179514).

\section{Results}

Bursaphelenchus xylophilus was detected in $22.8 \%$ of the samples corresponding to 114 samples collected in Calheta (1 sample), Funchal (51), Machico (20), Santa Cruz (16), Santana (9); and São Vicente (17) (Fig. 1).

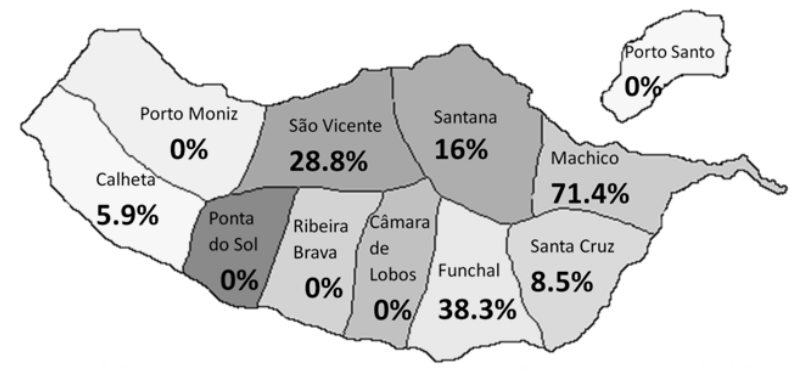

Fig. 1. Bursaphelenchus xylophilus infected Pinus pinaster wood samples per county in Madeira and Porto Santo Islands

\section{Morpho-biometrical characterisation}

The morphometry of 46 females and 52 males of the BxMad16S, BxMad18SC and BxMAd22C isolates collected from $P$. pinaster wood samples are shown in Table 2. Both females and males presented the general characters of the genus Bursaphelenchus (Nickle, 1970; EPPO, 2009): cephalic region high and offset by a constriction, with six lips; stylet with small basal thickenings; metacorpus well developed. The male tail was curved ventrally, with a small terminal bursa, which could be seen in dorso-ventral position, and the spicules were narrow, evenly arcuate, with a sharply pointed rostrum, capitullum flattened, condylus small, lamina angular in last third and a disc-like projection (cucullus) at the distal end (Fig. 2A). The female vulva clearly showed a distinct overlapping anterior lip (vulval flap) (Fig. 2B). In most females $(84.8 \%)$, the tail presented sub-cylindrical form with a broadly rounded tip (Fig. $2 \mathrm{C}$ ), or a digitate terminus with a terminal nipple-like extension resembling a mucro $(15.2 \%$ of the females) (Fig. 2D, E).

\section{PCR ITS-RFLP analysis}

Amplification of ITS regions yielded a single DNA fragment of approximately 950 bp for PWN isolates from Madeira Island (data not shown). The isolates presented a $B$. xylophilus specific ITS restriction pattern with the restriction endonucleases AluI, HaeIII, Hinfl, MspI and RsaI (Fig. 3) (Burgermeister et al., 2009; EPPO, 2009). The restriction pattern of Madeira Island isolates, with the restriction endonuclease $H h a \mathrm{I}$, showed the presence of four fragments with different sizes $(370 \mathrm{bp}, 190 \mathrm{bp}, 120 \mathrm{bp}$ and $110 \mathrm{bp}$ ), similar to the ITS restriction pattern obtained with the PWN virulent isolate (BxJS10) (Fig. 4) (Iwahori et al., 1998; Aikawa et al., 2003; Aikawa \& Kikuchi, 2007). 

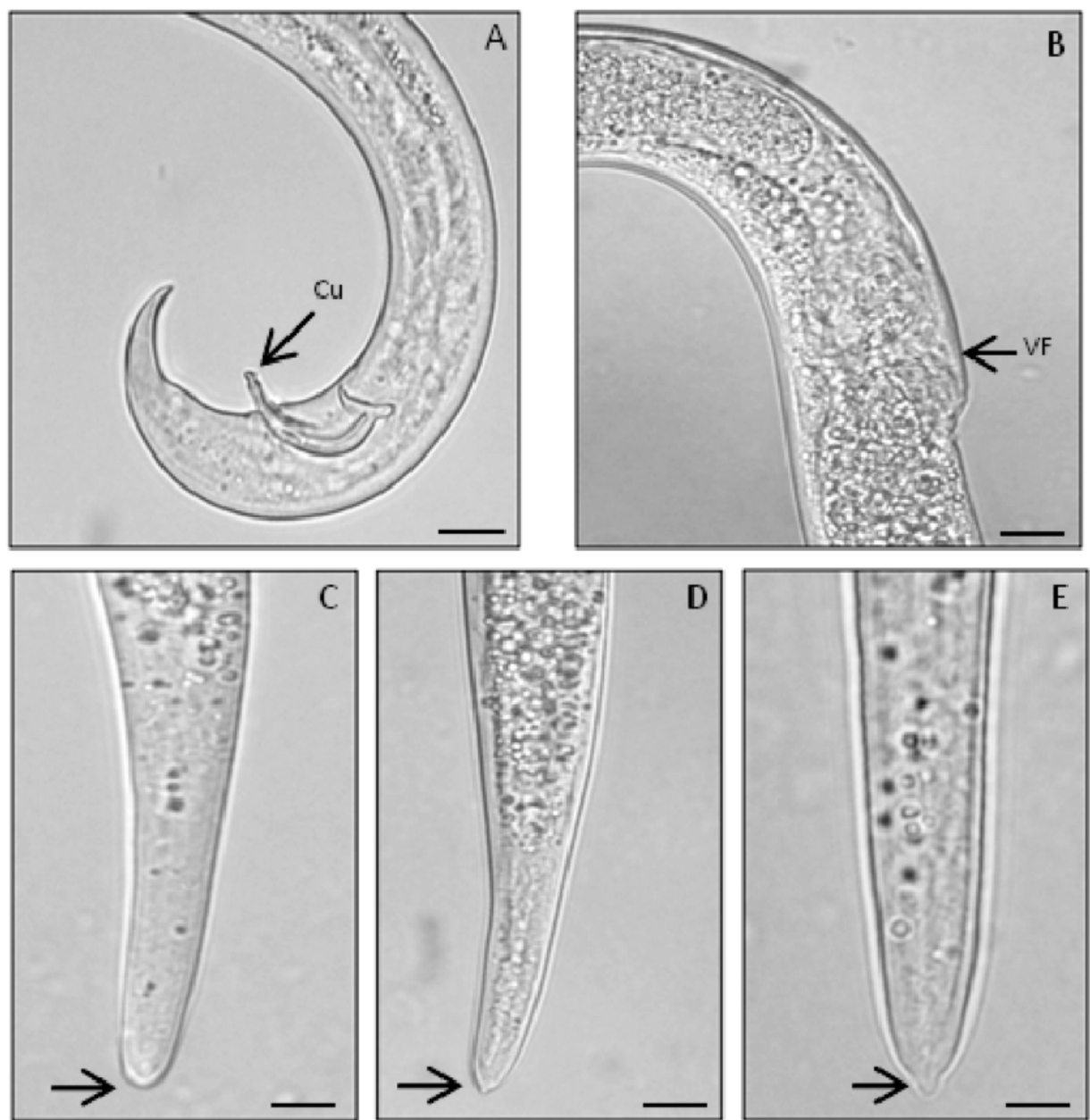

Fig. 2. Light microscope photographs of Bursaphelenchus xylophilus from Madeira Island. A: male tail; B: female vulval region; C: female rounded tail terminus: D. F: female tail terminus with a terminal ninnle-like extension resembling a mucro: VF: vulval flan: Cu: cucullus.

rDNA ITS sequencing and phylogenetic analysis

ITS nucleotide sequences ( 885 bp long for B. xylophilus isolates and 884 bp for B. mucronatus isolates) were submitted to GenBank under the accession numbers shown in Table 1. No genetic diversity was found in this genomic region among the 17 Portuguese isolates (Madeira Island

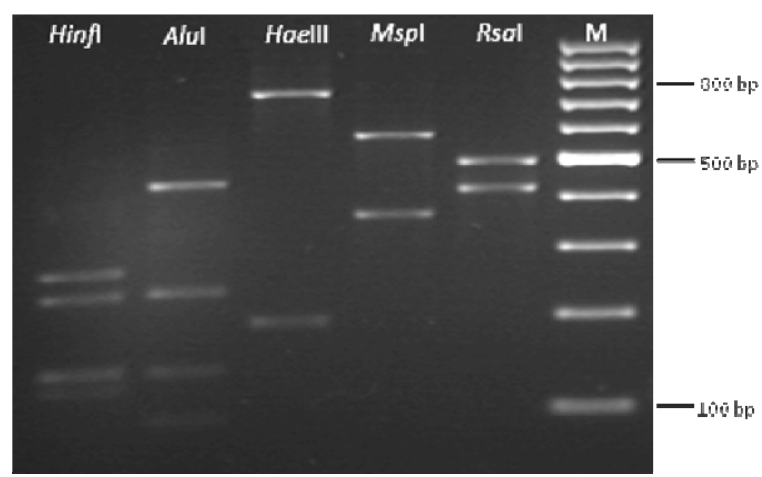

Fig. 3. ITS-RFLP pattern, with five restriction endonucleases, of Bursaphelenchus xylophilus from Madeira Island (BxMad18SC), obtained by digestion of the amplified rDNA fragment. M: DNA size marker (100 bp ladder, Fermentas). and Continental Portugal). Additionally, all Portuguese, Chinese and Korean B. xylophilus isolates share identical ITS sequences. An ITS sequence identity of $99.8 \%$ was found between the Spanish isolate and the Portuguese, Chinese and Korean isolates. The Japanese isolate (BxJS10) has an ITS sequence (acession number AB277206) identical to all Portuguese, Chinese and Korean isolates. Phylogenetic analysis revealed that Portuguese isolates grouped together with isolates from China, Korea and one isolate from Japan (BxJS10) (Group A). The Spanish isolate is positioned in a different branch of the same cluster. Bursaphelenchus xylophilus isolates from Canada, USA and some isolates from Japan are positioned in different clusters (Fig. 5).

\section{Discussion}

Once B. xylophilus is introduced into a non-native area, preventive measures have to be applied by removing dead or dying trees. Any uncut wilted tree and untreated dead wood can be a reservoir of nematodes, as well as insects, for the following year as insect vectors will emerge carrying large numbers of nematodes (Schrader \& Unger, 2003; Jones et al., 2008). The complex ecology of B. xylophilus 

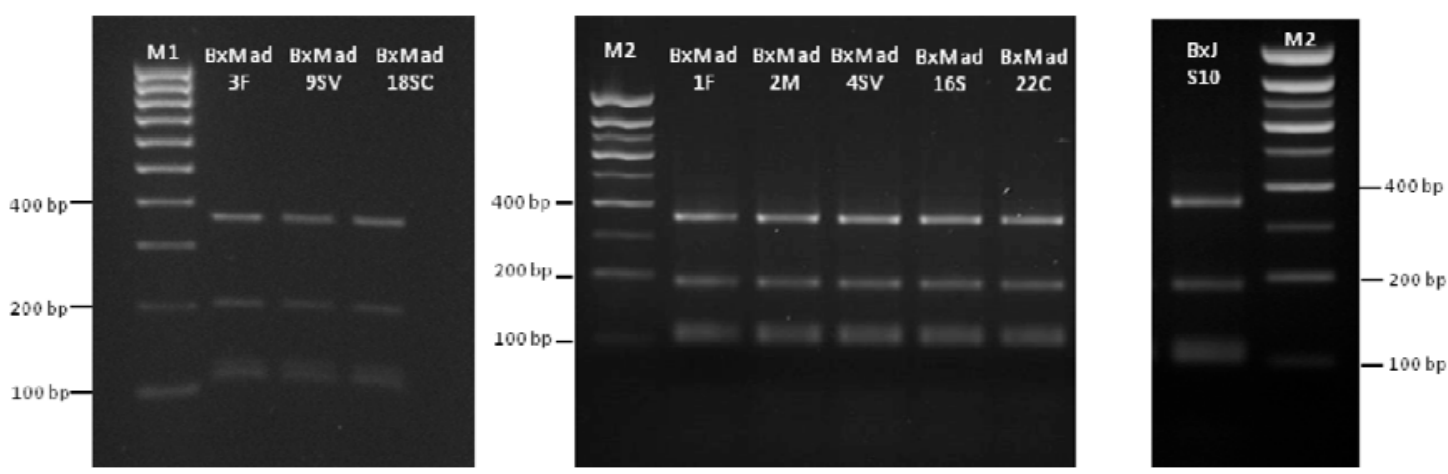

Fig. 4. ITS-RFLP pattern, with the restriction endonuclease HhaI, of eight Bursaphelenchus xylophilus isolates from Madeira Island and of a virulent Japanese B. xylophilus isolate (BxJS10) obtained by digestion of the amplified rDNA fragment. M1: DNA size marker (100 bp ladder, Fermentas); M2: DNA size marker (100 bp ladder, Bioline).

means that in order to spread the disease to a susceptible host, the nematode and the insect vector need to be present and combined with favorable temperatures. Serious PWD symptoms are associated with higher temperatures, occurring only where average summer temperatures exceed $20^{\circ} \mathrm{C}$ (Jones et al., 2008). In Madeira Island, after the first detection of PWN, an intensive survey has been conducted to evaluate the distribution of the nematode throughout the island and the PWN was detected in $22.8 \%$ of the analysed $500 P$. pinaster wood samples. The B. xylophilus isolates from Madeira Island characterised in this study presented the diagnostic characters (shape of the spicules, morphology of the vulval region and female tail shape) typical for B. xylophilus. However, a morphological variation in the female tail terminus was detected (Fig. 2). In most specimens, the tail terminus presented a broadly rounded tip. Some females presented a terminal nipple-like extension resembling a mucro. Variation in the shape of the female tails, from round, digitate to mucronate has been detected in PWN isolates from Continental Portugal (Penas et al., 2004; Fonseca et al., 2008a; Penas et al., 2008). Mucronate tailed females of PWN have also been reported in Japan and North America (Wingfield et al., 1983; Bolla \& Boschert, 1993). Furthermore, most of the morphometric data (Table 2) are within the range of other B. xylophilus isolates previously described (Mamiya \& Kiyohara, 1972; Nickle et al., 1981; Mota et al., 1999; Fonseca et al., 2008a; Penas et al., 2008).

Restriction patterns obtained by PCR ITS-RFLP has been routinely used to identify Bursaphelenchus species (Penas

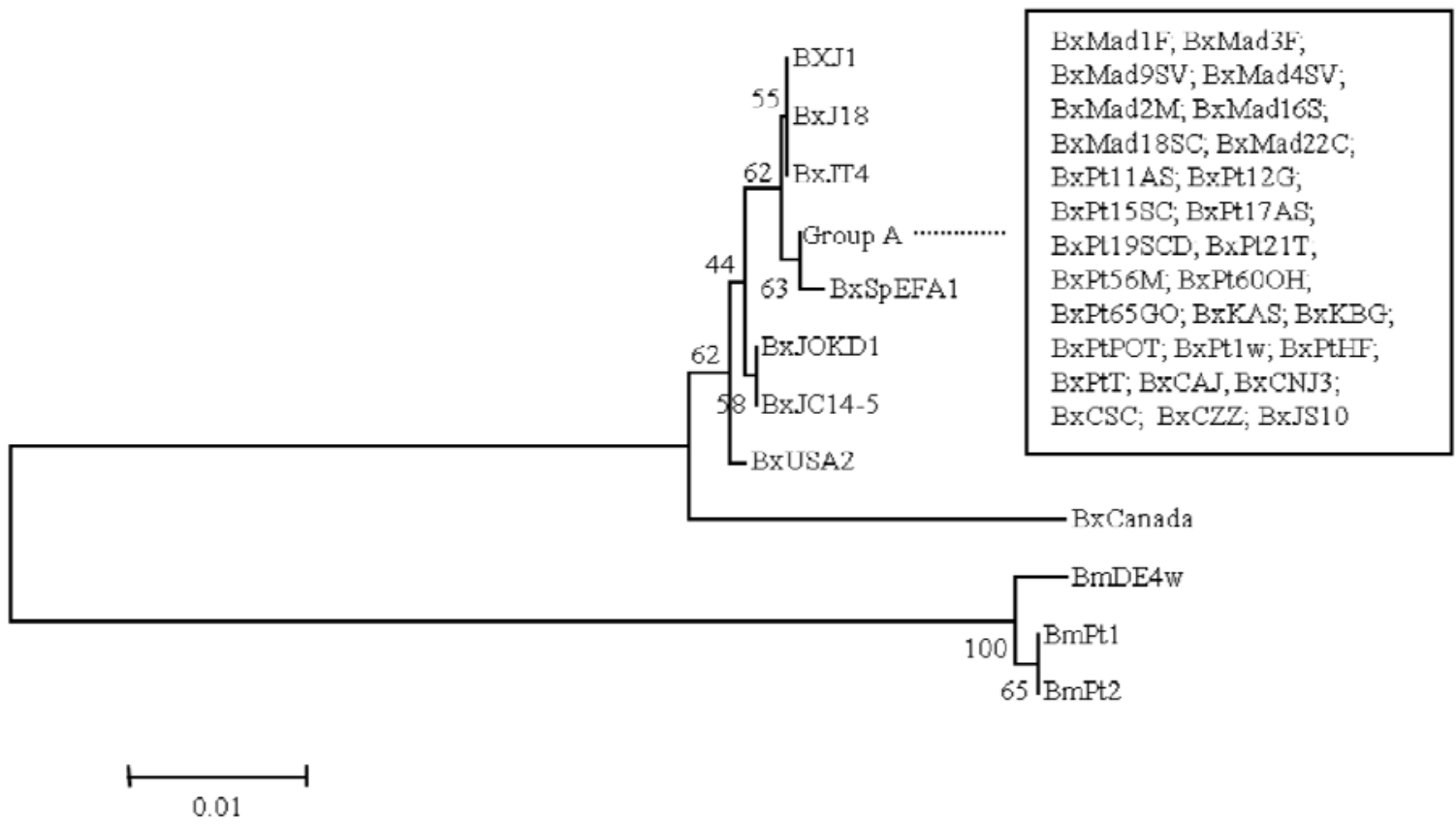

Fig. 5. Phylogenetic analysis. Neighbor-joining phylogenetic tree generated from the alignment of ITS sequences determined in this study for Bursaphelenchus xylophilus and B. mucronatus isolates and of other isolates present in GenBank database: BxPtPOT (Acession number EF446949), BxPt1w (AM157747), BxPtHF (AB277204), BxPtT (AB277208), BxSpEFA1 (HQ646254), BxCAJ (EF446945), BxCNJ3 (EF446944), BxCSC (EF446947), BxCZZ (EF446952), BxJT4 (AB277207), BxJ1 (EF446943), BxJ18 (AB294736), BxJS10 (AB277206), BxJOKD1 (AB277205), BxJC14-5 (AB277203), BxUSA2 (EEF446951), BxCanada (EF446946), BmDE4w (AM179514). 
Table 2. Morphometrics of females and males of Madeira Island Bursaphelenchus xylophilus isolates (BxMad16S, BxMad18SC and BxMAd22C) collected from Pinus pinaster samples. Values are mean \pm SD. Values in parentheses indicate the minimum and maximum.

\begin{tabular}{|c|c|c|c|c|c|c|}
\hline \multirow{3}{*}{$\frac{\text { Character }}{\text { Linear }(\mu \mathrm{m})}$} & \multicolumn{6}{|c|}{ B. xylophilus isolate } \\
\hline & \multicolumn{2}{|c|}{ BxMad16S } & \multicolumn{2}{|c|}{ BxMad18SC } & \multicolumn{2}{|c|}{ BxMad22C } \\
\hline & Females $(n=20)$ & Males $(\mathrm{n}=20)$ & Females $(n=16)$ & Males $(n=20)$ & Females $(n=10)$ & Males (n=12) \\
\hline Body length (L) & $\begin{array}{c}1043.2 \pm 143.2 \\
(773.3-1266.7)\end{array}$ & $\begin{array}{c}843.6 \pm 133.4 \\
(700.0-1086.7)\end{array}$ & $\begin{array}{c}1009.1 \pm 153.9 \\
(800.0-1200.0)\end{array}$ & $\begin{array}{c}828.6 \pm 107.7 \\
(656.7-1045.0)\end{array}$ & $\begin{array}{c}984.7 \pm 134.9 \\
(820.0-1173.3)\end{array}$ & $\begin{array}{c}863.6 \pm 128.0 \\
(713.3-1080.0)\end{array}$ \\
\hline Stylet length & $\begin{array}{c}12.6 \pm 0.8 \\
(11.1-14.2)\end{array}$ & $\begin{array}{c}12.5 \pm 1.0 \\
(11.3-14.5)\end{array}$ & $\begin{array}{c}12.0 \pm 1.1 \\
(10.5-14.5)\end{array}$ & $\begin{array}{c}11.6 \pm 0.6 \\
(10.8-12.9)\end{array}$ & $\begin{array}{c}11.6 \pm 0.7 \\
(10.5-12.6)\end{array}$ & $\begin{array}{c}11.9 \pm 0.9 \\
(10.8-13.4)\end{array}$ \\
\hline Greatest body width & $\begin{array}{c}28.0 \pm 4.3 \\
(18.3-35.0)\end{array}$ & $\begin{array}{c}24.0 \pm 3.2 \\
(18.3-28.3)\end{array}$ & $\begin{array}{c}27.6 \pm 3.3 \\
(21.7-33.3)\end{array}$ & $\begin{array}{c}20.3 \pm 3.0 \\
(16.7-26.7)\end{array}$ & $\begin{array}{c}25.2 \pm 3.3 \\
(20.0-28.3)\end{array}$ & $\begin{array}{c}22.1 \pm 3.4 \\
(16.7-28.3)\end{array}$ \\
\hline $\begin{array}{l}\text { Distance from } \\
\text { anterior end to end } \\
\text { of median bulb }\end{array}$ & $\begin{array}{c}72.9 \pm 5.6 \\
(63.2-85.0)\end{array}$ & $\begin{array}{c}68.4 \pm 5.7 \\
(55.8-78.7)\end{array}$ & $\begin{array}{c}74.1 \pm 5.8 \\
(64.7-86.8)\end{array}$ & $\begin{array}{c}68.6 \pm 4.9 \\
(60.3-79.1)\end{array}$ & $\begin{array}{c}71.8 \pm 4.9 \\
(63.7-77.4)\end{array}$ & $\begin{array}{c}70.5 \pm 5.8 \\
(64.2-80.3)\end{array}$ \\
\hline $\begin{array}{l}\text { Distance from } \\
\text { anterior end to } \\
\text { vulva }\end{array}$ & $\begin{array}{c}761.6 \pm 105.9 \\
(560.0-932.3)\end{array}$ & - & $\begin{array}{c}737.0 \pm 121.9 \\
(564.7-906.7)\end{array}$ & - & $\begin{array}{c}702.6 \pm 111.4 \\
(561.9-875.0)\end{array}$ & - \\
\hline $\begin{array}{l}\text { Distance from } \\
\text { anterior end to anus } \\
\left(L^{\prime}\right)\end{array}$ & $\begin{array}{c}1005.3 \pm 139.7 \\
(746.8-1227.5)\end{array}$ & $\begin{array}{c}806.6 \pm 132.0 \\
(666.6-1043.0)\end{array}$ & $\begin{array}{c}972.8 \pm 151.5 \\
(765.8-1163.2)\end{array}$ & $\begin{array}{c}793.3 \pm 106.3 \\
(621.4-1007.6)\end{array}$ & $\begin{array}{c}947.9 \pm 133.2 \\
(788.4-1141.2)\end{array}$ & $\begin{array}{c}829.5 \pm 125.7 \\
(680.7-1036.8)\end{array}$ \\
\hline $\begin{array}{l}\text { Distance from } \\
\text { vulva to anus }\end{array}$ & $\begin{array}{c}242.3 \pm 41.5 \\
(186.3-323.2)\end{array}$ & - & $\begin{array}{c}233.2 \pm 31.5 \\
(190.3-280.8)\end{array}$ & - & $\begin{array}{c}249.1 \pm 21.2 \\
(226.5-287.4)\end{array}$ & - \\
\hline Tail length & $\begin{array}{c}38.0 \pm 5.1 \\
(26.5-45.3)\end{array}$ & $\begin{array}{c}36.9 \pm 4.2 \\
(29.0-44.2)\end{array}$ & $\begin{array}{c}36.3 \pm 4.1 \\
(31.6-44.7)\end{array}$ & $\begin{array}{c}35.0 \pm 3.2 \\
(27.9-41.6)\end{array}$ & $\begin{array}{c}37.1 \pm 4.7 \\
(31.6-44.7)\end{array}$ & $\begin{array}{c}34.1 \pm 3.9 \\
(30.0-43.2)\end{array}$ \\
\hline Body width at anus & $\begin{array}{c}11.3 \pm 1.2 \\
(9.2-12.9)\end{array}$ & $\begin{array}{c}16.0 \pm 1.7 \\
(12.4-19.2)\end{array}$ & $\begin{array}{c}11.1 \pm 1.2 \\
(9.0-13.2)\end{array}$ & $\begin{array}{c}15.2 \pm 2.1 \\
(12.1-19.5)\end{array}$ & $\begin{array}{c}11.3 \pm 1.2 \\
(9.0-13.2)\end{array}$ & $\begin{array}{c}16.4 \pm 1.9 \\
(13.2-19.5)\end{array}$ \\
\hline Spicule length & - & $\begin{array}{c}28.3 \pm 2.8 \\
(23.7-32.6)\end{array}$ & - & $\begin{array}{c}25.4 \pm 2.1 \\
(21.8-31.8)\end{array}$ & - & $\begin{array}{c}27.6 \pm 2.5 \\
(23.2-31.3)\end{array}$ \\
\hline $\begin{array}{l}\text { Body width at } \\
\text { vulva }\end{array}$ & $\begin{array}{c}25.4 \pm 3.8 \\
(16.6-31.8)\end{array}$ & - & $\begin{array}{c}24.6 \pm 3.5 \\
(19.0-33.2)\end{array}$ & - & $\begin{array}{c}24.1 \pm 3.6 \\
(17.4-28.2)\end{array}$ & - \\
\hline \multicolumn{7}{|l|}{ Ratio } \\
\hline $\begin{array}{l}a=L / \text { greatest body } \\
\text { width }\end{array}$ & $\begin{array}{c}37.5 \pm 3.2 \\
(33.1-44.1)\end{array}$ & $\begin{array}{c}35.2 \pm 3.6 \\
(30.1-40.1)\end{array}$ & $\begin{array}{c}37.1 \pm 5.9 \\
(30.0-45.3)\end{array}$ & $\begin{array}{c}41.2 \pm 4.3 \\
(33.2-49.2)\end{array}$ & $\begin{array}{c}39.2 \pm 4.9 \\
(33.7-48.2)\end{array}$ & $\begin{array}{c}39.4 \pm 4.7 \\
(31.7-47.3)\end{array}$ \\
\hline $\begin{array}{l}\mathrm{b}_{1}=\mathrm{L} / \text { distance from } \\
\text { anterior end to end } \\
\text { of median bulb }\end{array}$ & $\begin{array}{c}14.3 \pm 1.6 \\
(11.1-16.9)\end{array}$ & $\begin{array}{c}12.4 \pm 1.8 \\
(10.3-16.4)\end{array}$ & $\begin{array}{c}13.7 \pm 2.2 \\
(10.4-16.8)\end{array}$ & $\begin{array}{c}12.1 \pm 1.3 \\
(10.0-15.0)\end{array}$ & $\begin{array}{c}13.7 \pm 1.4 \\
(11.9-15.5)\end{array}$ & $\begin{array}{c}12.2 \pm 1.4 \\
(10.6-14.8)\end{array}$ \\
\hline $\mathrm{c}=\mathrm{L} /$ tail length & $\begin{array}{c}27.6 \pm 2.5 \\
(23.0-31.4)\end{array}$ & $\begin{array}{c}23.0 \pm 3.8 \\
(18.8-32.2)\end{array}$ & $\begin{array}{c}27.8 \pm 3.5 \\
(23.3-33.0)\end{array}$ & $\begin{array}{c}23.7 \pm 2.6 \\
(20.2-29.2)\end{array}$ & $\begin{array}{c}26.7 \pm 3.4 \\
(22.3-32.8)\end{array}$ & $\begin{array}{c}25.5 \pm 3.0 \\
(21.9-32.0)\end{array}$ \\
\hline $\begin{array}{l}c^{\prime}=\text { tail length/body } \\
\text { width at anus }\end{array}$ & $\begin{array}{c}3.4 \pm 0.4 \\
(2.5-3.8)\end{array}$ & $\begin{array}{c}2.3 \pm 0.3 \\
(1.8-2.7)\end{array}$ & $\begin{array}{c}3.3 \pm 0.5 \\
(2.5-4.1)\end{array}$ & $\begin{array}{c}2.3 \pm 0.2 \\
(1.8-2.6)\end{array}$ & $\begin{array}{c}3.3 \pm 0.3 \\
(2.7-3.5)\end{array}$ & $\begin{array}{c}2.1 \pm 0.3 \\
(1.7-2.5)\end{array}$ \\
\hline \multicolumn{7}{|l|}{ Percentage } \\
\hline $\begin{array}{l}\mathrm{V}=\text { distance from } \\
\text { anterior end to } \\
\text { vulva } \times 100 / \mathrm{L}\end{array}$ & $\begin{array}{c}73.0 \pm 1.7 \\
(69.5-76.2)\end{array}$ & - & $\begin{array}{c}72.9 \pm 2.0 \\
(70.1-75.6)\end{array}$ & - & $\begin{array}{c}71.2 \pm 1.7 \\
(71.3-77.5)\end{array}$ & - \\
\hline $\begin{array}{l}\mathrm{V}=\text { distance from } \\
\text { anterior end to } \\
\text { vulva } \times 100 / \mathrm{L}\end{array}$ & $\begin{array}{c}75.7 \pm 1.9 \\
(71.9-79.3) \\
\end{array}$ & - & $\begin{array}{c}75.7 \pm 1.9 \\
(72.6-78.0) \\
\end{array}$ & - & $\begin{array}{c}74.0 \pm 1.7 \\
(71.3-77.5)\end{array}$ & - \\
\hline
\end{tabular}

et al., 2004; Urek et al., 2007; Akbulut et al., 2008; Burgermeister et al., 2009). The ITS-RFLP patterns for the Madeira Island isolates were specific to the species $B$. xylophilus (Fig. 3) and identical to restriction patterns revealed by other PWN isolates from Continental Portugal and other parts of the world (Mota et al., 1999; Penas et al., 2004; Burgermeister et al., 2009; EPPO, 2009). The ITS restriction pattern with $H$ haI revealed a pattern (Fig. 4) 
similar to the ITS restriction pattern obtained with BxJS10, a virulent isolate (Iwahori et al., 1998; Aikawa et al., 2003). ITS restriction analysis of PWN isolates from Continental Portugal with the same restriction endonuclease also yielded PWN virulent ITS restriction patterns (Fonseca et al., 2008b). From the ITS sequencing results, the Madeira Island isolates were clearly identified as members of the B. xylophilus species and no genetic diversity was found for this genomic region between the Portuguese PWN isolates (Madeira Island and Continental Portugal) Chinese, Korean isolates and one Japanese isolate (BxJS10). Previous studies have already reported the complete ITS sequence identity between three Portuguese isolates, six Chinese isolates and BxJS10 (Mota et al., 2006; Zhang et al., 2008). The Portuguese isolates grouped together with those isolates and close to the Spanish isolate (Fig. 5). This is consistent with the low genetic variability found between 24 Portuguese isolates and one Chinese isolate revealed by RAPD analysis (Vieira et al., 2007). Bursaphelenchus xylophilus isolates from Canada, USA and some isolates of Japan positioned in different clusters. Japanese isolates revealed higher genetic diversity, as previously described (Zhang et al., 2008). Extended phylogenetic studies using other PWN genomic regions are being undertaken in order to better understand the origin and spread of this species in Portugal and worldwide.

The presence of B. xylophilus in Madeira Island is reported for the first time. The spread and fast establishment of this nematode and consequent pine forest devastation leading to economic damage, as well as the threatening of forest ecosystems, obliges the development and/or improvement of quarantine regulations in order to control the dissemination of the nematode to non-affected areas.

\section{Acknowledgments}

This research was partially supported by Direcção Regional de Florestas, Fundo Florestal Permanente and Autoridade Florestal Nacional, through a national project "O nemátode-da-madeira-do-pinheiro (NMP), Bursaphelenchus xylophilus", FEDER funds through the Programa Operacional Factores de Competitividade (COMPETE) and national funds through FCT (Fundação para a Ciência e a Tecnologia) under the project PTDC/AGRCFL/098916/2008. J. M. S. Cardoso is funded by FCT (Post-doctoral fellowship SFRH/BPD/73724/2010).

\section{References}

Abelleira, A., Picoaga, A., Mansilla, J. P., Aguin, O. (2011): Detection of Bursaphelenchus xylophilus, causal agent of pine wilt disease on Pinus pinaster in Northwestern Spain. Plant Dis., 95: 776 - 776. DOI: 10.1094/pdis12-10-0902

AIKAWA, T., KIKUCHI, T. (2007): Estimation of virulence of Bursaphelenchus xylophilus (Nematoda: Aphelenchoididae) based on its reproductive ability. Nematology, 9: $371-377$
AiKawa, T., KiKuchi, T., KosaKa, H. (2003): Demonstration of interbreeding between virulent and avirulent populations of Bursaphelenchus xylophilus (Nematoda: Aphelenchoididae) by PCR-RFLP method. Appl. Entomol. Zoolog., 38: $565-569$

Akbulut, S., Vieira, P., Ryss, A., Valadas, V., Keten, A., MotA, M. (2008): Bursaphelenchus Fuchs, 1937 (Nematoda: Parasitaphelenchidae) species associated with Pinus species in northern Turkey. Helminthologia, 45: $89-$ 95. DOI: 10.2478/s11687-008-0017-0

Altschul, S. F., Madden, T. L., Schaffer, A. A., Zhang, J. H., Zhang, Z., Miller, W., Lipman, D. J. (1997): Gapped BLAST and PSI-BLAST: a new generation of protein database search programs. Nucleic Acids Res., 25: 3389 - 3402

Bolla, R. I., Boschert, M. (1993): Pinewood nematode species complex: interbreeding potencial and chromosome number. J. Nematol., 25: 227 - 238

BraAsch, H., Schonfeld, U., Polomski, J., BurgerMEISTER, W. (2004): Bursaphelenchus vallesianus sp. n. A new species of the Bursaphelenchus sexdentati group (Nematoda: Parasitaphelenchidae). Nematol. Medit., 32: 71 $-79$

Burgermeister, W., Braasch, H., Metge, K., Gu, J. F., Schroder, T., WoldT, E. (2009): ITS-RFLP analysis, an efficient tool for differentiation of Bursaphelenchus species. Nematology, 11: 649 - 668. DOI: 10.1163/15685410 $8 / 399182$

EPPO (2009): Diagnostic protocols for regulated pests: Bursaphelenchus xylophilus. Bulletin OEPP/EPPO, 31: 61 $-69$

Erber, D., Aguiar, A. M. F. (1996): New and remarkable species of the coleopterous fauna of Madeira. Boletim do Museu Municipal do Funchal, 48: 41 - 62

FERRIS, V. R., FERRIS, J. M., FAGHIHI, J. (1993): Variation in spacer ribosomal DNA in some cyst-forming species of plant parasitic nematodes. Fundam. Appl. Nematol., 16: $177-184$

Fonseca, L., SAntos, M. C. V., SAntos, M. S., Curtis, R. H. C., Abrantes, I. M. O. (2008a): Morpho-biometrical characterisation of Portuguese Bursaphelenchus xylophilus isolates with mucronate, digitate or round tailed females. Phytopathol. Mediterr., 47: 223 - 233

Fonseca, L., Vieira Dos Santos, M. C., Curtis, R. H. C., ABRANTES, I. M. O. (2008b): Insights into virulence of Portuguese Bursaphelenchus xylophilus isolates by ITSRFLP analysis. Abstracts of the International Nematology Congress, Brisbane, Australia: p327.

HALL, T. A. (1999): BioEdit: a user-friendly biological sequence alignment editor and analysis program for Windows 95/98/NT. Nucl. Acids Symp. Ser., 41: 95 - 98

HOOPER, D. J. (1986): Extraction of nematodes from plant material. In J. F. Southey (ed) Laboratory methods for work with plant and soil nematodes. London: Ministry of Agriculture, Fisheries and Food, pp. 51.

IWAHORI, H., TSUDA, K., KANZAKI, N., IZUI, K., FUTAI, K. (1998): PCR-RFLP and sequencing analysis of ribosomal DNA of Bursaphelenchus nematodes related to pine wilt 
disease. Fundam. Appl. Nematol., 21: 655 - 666

Jones, J. T., Moens, M., MotA, M., LI, H. M., KiKUCHI, T. (2008): Bursaphelenchus xylophilus: opportunities in comparative genomics and molecular host-parasite interactions. Mol. Plant Pathol., 9: 357 - 368. DOI: 10.1111/j.13643703.2007.00461.x

MAMIYA, Y., KIYOHARA, T. (1972): Description of Bursaphelenchus lignicolus (Nematoda: Aphelenchoididae) from pine wood and histopathology of nematode infested trees. Nematologica, 18: 120 - 124

Mota, M. M., Braasch, H., Bravo, M. A., Penas, A. C., Burgermeister, W., Metge, K., SousA, E. (1999): First report of Bursaphelenchus xylophilus in Portugal and in Europe. Nematology, 1: $727-734$

Mota, M. M., TAKemoto, S., Takeuchi, Y., Hara, N., FUTAI, K. (2006): Comparative studies between Portuguese and Japanese isolates of the pinewood nematode, Bursaphelenchus xylophilus. J. Nematol., 38: 429 - 433

NiCKLE, W. R. (1970): A taxonomic review of the genera of the Aphelenchoidea (Fuchs, 1937) Thorne, 1949 (Nematoda: Tylenchida). J. Nematol., 2: 375 - 392

Nickle, W. R., Golden, A. M., MamiYA, Y., Wergin, W. P. (1981): On the taxonomy and morphology of pine wood nematode, Bursaphelenchus xylophilus (Steiner and Buhrer 1934). J. Nematol., 13: 385 - 392

Penas, A. C., Bravo, M. A., Valadas, V., Mota, M. (2008): Detailed morphobiometric studies of Bursaphelenchus xylophilus and characterisation of other Bursaphelenchus species (Nematoda: Parasitaphelenchidae) associated with Pinus pinaster in Portugal. J. Nematode Morphol. Syst., 10: $137-163$

Penas, A. C., Correia, P., Bravo, M. A., Mota, M., TENREIRO, R. (2004): Species of Bursaphelenchus Fuchs, 1937 (Nematoda: Parasitaphelenchidae) associated with maritime pine in Portugal. Nematology, 6: 437 - 453. DOI: 10.1023/B:NEMT.0000046914.00963.df

PORTARIA (n. ${ }^{\circ}$ 8/2010): Secretaria Regional do Ambiente e dos Recursos Naturais. Jornal oficial da Região Autónoma da Madeira, Série I No 11: 3 - 10

Robertson, L., Arcos, S. C., Escuer, M., Merino, R. S., Esparrago, G., Abellera, A., Navas, A. (2011): Inci- dence of the pinewood nematode Bursaphelenchus xylophlius Steiner \& Buhrer, 1934 (Nickle, 1970) in Spain. Nematology, 13: 755 - $757 . \quad$ DOI: $10.1163 / 138855411 \times 578888$

SAITOU, N., NEI, M. (1987): The Neighbor-Joining method - a new method for reconstructing phylogenetic trees. Mol. Biol. Evol., 4: 406 - 425

Schrader, G., Unger, J. (2003): Plant quarantine as a measure against invasive alien species: the framework of the International Plant Protection Convention and plant health regulations in the European Union. Biol. Invasions, 5: $357-364$

Tamura, K., Dudley, J., Nei, M., Kumar, S. (2007): MEGA4: Molecular Evolutionary Genetics Analysis (MEGA) Software Version 4.0. Mol. Biol. Evol., 24: 1596 - 1599. DOI: $10.1093 / \mathrm{molbev} / \mathrm{msm} 092$.

UREK, G., SircA, S., Geric, B. (2007): Morphometrical and molecular characterization of Bursaphelenchus species from Slovenia. Helminthologia, 44: 37 - 42. DOI: 10.2478/s11687-007-0001-0

Vieira, P., Burgermeister, W., Mota, M., Metge, K., SILVA, G. (2007): Lack of genetic variation of Bursaphelenchus xylophilus in Portugal revealed by RAPD-PCR analyses. J. Nematol., 39: $118-126$

VRAIN, T. C. (1993): Restriction Fragment Length Polymorphism separates species of the Xiphinema americanum group. J. Nematol., 25: 361 - 364

WhiteheAd, A. G., HeMming, J. R. (1965): A comparison of some quantitative methods of extracting small vermiform nematodes from soil. Ann. Appl. Biol., 55: 25 - 38

Wingfield, M. J., Blanchette, A., Kondo, E. (1983): Comparison of the pine wood nematode, Bursaphelenchus xylophilus from pine and balsam fir. Eur. J. Forest Pathol., 13: $360-372$

Zhang, K. Y., LIU, H., SUn, J., LiU, J. R., FEI, K., ZhANG, C. X., XU, M. X., MA, X. Y., LAI, R., WU, Y. D., LIN, M. S. (2008): Molecular phylogeny of geographical isolates of Bursaphelenchus xylophilus: implications on the origin and spread of this species in China and worldwide. J. Nematol., 40: $127-137$ 